\title{
高能率火焰ジェットバーナおよび過熱蒸気 バーナの開発に関する研究*
}

\author{
外尾善次郎 ${ }^{1}$ 島 田 荘 平 ${ }^{2}$ \\ 馬 場 敬 之 之 $^{3}$
}

\section{1. まえがき}

超音速の火焰ジェットバーナは, 岩石削孔や岩石切截だ けでなく，広く産業界に利用されるようになつてきた。

各種産業廃棄物の処理に, また岩石その他固形物の粉砕 または微粉砕等に用いることによつて, 他の方法にみられ ぬ利点と経済効果をあげうる見通しがついてきた。しかし， この場合, 従来開発していた岩石削孔用の空気ケロシン系 火焰ジェットバーナは, 熱効率 ${ }^{a)}$ の点で必らずしも満足し うるものではなく, 熱損失量は 25～27\%にも達していた。 これは，バーナ自体が岩石削孔用として開発されたもので あつたため, 削孔径にあわせてバーナ燃焼筒の径 $(D)$ を小 さくとらざるを得ないという制約上，燃焼に必要な一定の 燃焼筒容積を確保するためには, 非常に細長い燃焼筒（長 さ $L$ ) とせざるを得なかつたためである。 $L / D=10 \sim 15$ としているため, 燃焼筒の外側を流れる冷却水と, 燃焼筒 外壁面との接触面積も大きくなり，したがつて然焼筒から 冷却水へ伝達される熱量 ( 熱損失 ) も大きく, 燃焼筒内で の発生熱量の $25 \sim 27 \%$ が熱損失となつていた。バーナを 長期運転する場合，これは相当大きな経済上のマイナスを もたらす。削孔以外に利用する場合には, 燃焼筒径の制限 はなくなるため， $D$ と $L$ と関係もまた任意にとることが できる。もし熱損失を $10 \%$ 以下に減少させることができれ ば, 非常に大きな経済性が生ずる。熱損失を $10 \%$ 以下に 减らすことを目標に, 構造的にも従来のものとは全く異な つたものを開発し，その目的を達成することができた。

さらに廃棄物処理の場合や固形物 (特に岩石以外の有機 物や化学製品等 ) の粉砕を行なう場合, 火焰ジェットの温 度を低くしたいという要求が生じた。火焰ジェットはノズ ル出口温度で, 約 $2,000^{\circ} \mathrm{K}$ とう高温であるため, これを 岩石等以外の固形物に噴射すると, 燃焼はしなくても高温 のため炭化あるいは熱分解する。処理対象物に応じて, ジ ェットの温度を任意に変化させることができ, しかも圧力 はできるだけ元の圧力を維持できれば, 火焰ジェットバー

* 1981 年 8 月 31 日受理

1. 正会員工博 東京大学教授工学部資源開発工学科

2. 正会員 工博 東京大学助教授 工学部資源開発工学科

3. 正会員 東京大学大学院博士課程 工学部資源開発工学科

a) 発生熱量に対する有効利用熱量の比。バーナ燃焼筒は水冷している ので, 発生熱量の一部は冷却水の方へ失なわれる。
ナの産業界での利用範囲が非常に拡大することになる。火 焰ジェットと水を用いて過熱蒸気を発生させ, 水量を変化 させることによつて任意の温度の過熱蒸気を発生させるこ とができ, かつ超音速流として圧力 $5 \sim 6$ 気圧 ( 火焰ジェ ット圧力 $6 \sim 6.5$ 気圧の場合) て噴射できる装置 (過熱蒸 気バーナと呼ぶ ) を開発した。以下開発のために実施した 実験の結果と設計上の検討, これらバーナの構造, 特性に ついて報告する。

\section{2. 高能率火焰ジェットバーナの構造}

新しく開発したバーナの構造を第 1 - a 図に示している。 大別して燃焼筒(1)，ノズル(2)，インジェクタ(3), スワーラ 本体(4)からなる。燃料はインジェクタ(3)より噴霧状で然焼 筒内一噴射され，圧縮空気はスワーラ本体（第 $1-\mathrm{b}$ 図）

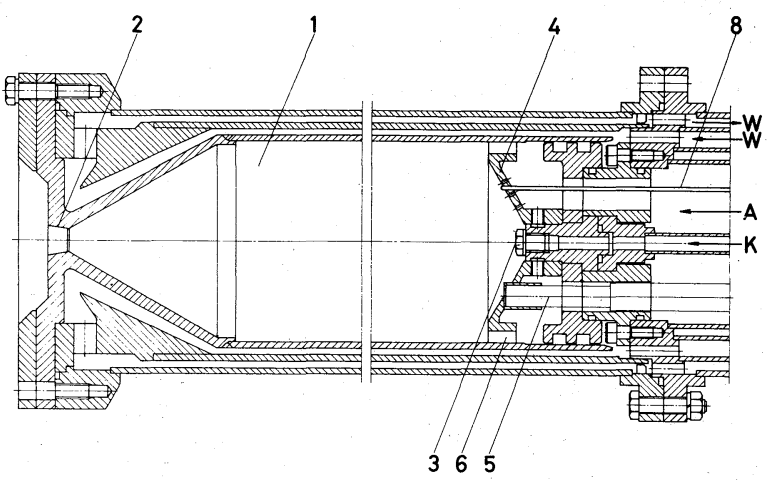

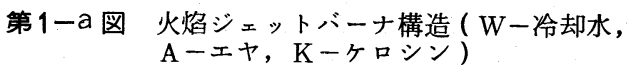

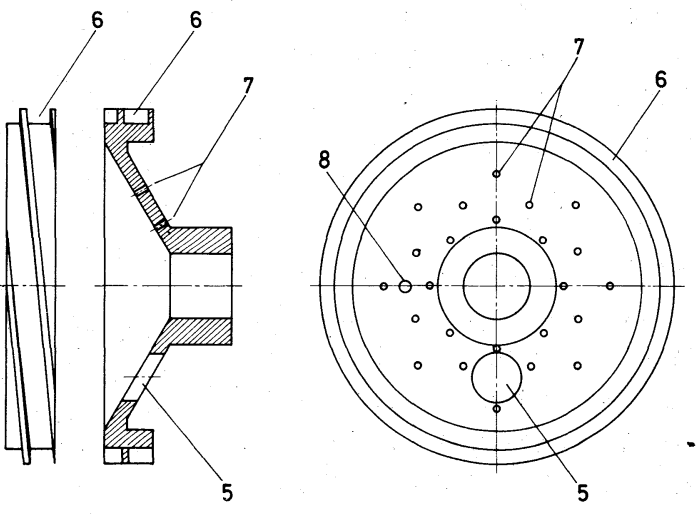

第1ーb 図 スワーラ本体の構造（ 5 -点火装置用の孔， 8 - 熱電対用孔) 
にあけられている小孔群(7)からその一部が燃焼筒内一噴射 され，これは燃料と衝突してその噴霧性を向上させる。残 りの空気は, スワーラ本体の外周部に設けられたスワーラ 溝(6)を流れ, 旋回流となつて燃焼筒内壁面に沿つて流れ, 燃焼筒内壁面に燃焼高温ガスが直接接触することを防ぎ， 冷却水への燃焼筒壁面からの熱損失を減少させる役目を果 たす。もちろんこの空気も燃焼に参加するが，スワーラ本 体からある距離の間は, 熱損失を減少させる働きをする筈 である。このバーナには点火装置(5)が内蔵されており, そ の先端の放電火花によつて容易に点火され, 燃焼が開始さ れる。点火による燃焼開始は, 指入されてる熱電対(8)に よつて, 直ちに確認することができる。、燃焼筒の外側には 冷却水が循環して, 燃焼筒を保護しているのは従来方式の ものと変らない。スワーラ溝(6)は一定のピッチをもち, あ る深さと幅をもつへリカルな 4 条の溝である。溝の断面積 は, ここを流れる空気流速が, 旋回流と噴射流と同じにな るとして, 設計されている。

\section{3. スワーラ本体の最適構造}

\section{$3 \cdot 1$ 空気過剩係数 $(\alpha)^{\mathrm{b})}$ と熱損失との関係}

スワーラ本体は第 1 - b 図に示すように, 外周に 4 条の スワーラ溝(6)が設けられており，ここを流れる旋回流量 $Q_{1}$ と, 多くの空気噴射小孔群(7)を流れる流量 $Q_{2}$ の割合 $\left(n=Q_{1} / Q_{2}\right.$, 以下流量比とよぶ ) を, どのようにとるか によつて, 燃焼筒内での空気燃料混合物の燃焼の安定性が 左右され, また熱損失量も変化する。またスワーラ溝を流 れる空気の流速, これと同じ速度の小孔群(7)から噴射され る空気流速 $(v)$ の大きさも, 空気燃料混合物の着火性や着 火後の燃焼状況に大きな影響を及ぼす。すなわちスワーラ 本体の構造とデイメンションが, バーナの性能を大きく左 右する。筆者らは, 空気噴射小孔(7)の直径と個数, 空気流 量比 $n$ を変えた 11 種類のスワーラ本体を試作し 噴射条件 を変えてその着火性，燃焼状況，および熱損失量を調べた。 ただし，いずれのスワーラ本体も第 1 - b 図に示すような 同じ傾斜の円錐台状をなしている。なお試作バーナは然料 （灯油）供給量 $0.3 \mathrm{l} / \mathrm{min}$ のものである。第 2 図にこの 11 種類のスワーラ本体を用いたときの空気過剰係数 $\alpha$ と 熱損失 (\%) との関係を示している。ただしこれは燃焼筒長 さ $(L)$ と燃焼筒内径 $(D)$ との比 $L / D=2.89$ の場合であ る。前述のようにスワーラ本体は, No.0からNo.10 -まで 11 種類のもので, $n=Q_{1} / Q_{2}$ と空気噴射小孔群(7)からの 噴射速度 $v(\mathrm{~m} / \mathrm{sec})$ は, それぞれ第 1 表のようになるよ うに設計されている。

第 2 図で矢印が付いているのは, それ以下の $\alpha$ 值の場合 には，黒煙が発生して燃焼状況が覀くなる限界を示してい

b) 供給然料量に対寸る所要空気流量と実空気流量との比 $(\alpha)$ 。ケロシン $1 \mathrm{~kg}$ が完全然焼するのには, 空気 $15 \mathrm{~kg}$ が必要。 $(\alpha=1.0)$, 空気流量 が $15 \mathrm{~kg}$ 以上の場合は過剩空気流量で $\alpha>1.0,15 \mathrm{~kg}$ 以下の場合は 空気不足で不完全然焼する $(\alpha>1.0)$ 。

\begin{tabular}{r|r|r||r|r|c}
\multicolumn{7}{c}{ 第 1 表 } \\
\hline No. & $n=Q_{1} / Q_{2}$ & \multicolumn{1}{c|}{$v$} & \multicolumn{1}{c}{ No. } & $n$ & $v$ \\
\hline 0 & 2.0 & 40.7 & 6 & 1.4 & 12.6 \\
1 & 2.1 & 8.6 & 7 & 2.4 & 15.3 \\
2 & 2.0 & 14.3 & 8 & 1.7 & 16.1 \\
3 & 2.0 & 17.3 & 9 & 1.2 & 14.0 \\
4 & 3.0 & 47.6 & 10 & 1.5 & 38.4 \\
5 & 3.7 & 20.4 & & & \\
\hline
\end{tabular}

る。例えば, No.9では $\alpha=1.08$ 以下の噴射条件では, 火 焰ジェットに黒煙が発生するごとを示している。第 2 図か らわかるように，噴射燃焼状況が最も良好であつたのは，

No. 10 のもので, $\alpha$ 值が 1.0 以下になつても, 肉眼ではほ とんど黒煙の発生はみられず, 熱損失量も最低である。熱 損失は, 一定量 $(40 \mathrm{l} / \mathrm{min})$ の供給冷却水量と, 排出冷 却水量との温度差を精密に測定することにより求めた。な お, この場合の火焰ジェットバーナ燃焼筒の内径は 109 $\mathrm{mm}$, 燃焼筒の長さは $315 \mathrm{~mm}$ で, 前述のように $L / D=$ 2.89 である。熱損失だけでなく, 着火性の良否も実用上 は重要である。

\section{$3 \cdot 2$ 流量比 $(\boldsymbol{n})$ と熱損失之の関係}

スワーラ溝を流れる空気量 $Q_{1}$ と, 同心円状に配置した空 気噴射小孔群から噴射される空気量 $Q_{2}$ との比,すなわち流 量比 $n$ の值によつて, 燃焼筒壁面から冷却水へ伝達される 熱損失量も変化し, かつ燃焼の安定性も変化する。 $n$ の值 を変化させた場合の熱損失の変化を, 空気過利係数 $\alpha$ 変 化に対応して求めたものが，第 3 図に示されている。これ からわかるように, $n=1.5$ の場合, すなわち $Q_{1}: Q_{2}=$ $6: 4$ の場合が最も好ましいことがわかる。第 2 図でNo. 10 のデータが, $n=1.5$ の場合である。

\section{4. 燃焼筒内径 $(\boldsymbol{D})$ と燃焼筒長さ $(\boldsymbol{L})$ との関係}

燃焼に必要な一定の燃焼筒容積を確保する場合, 燃焼筒

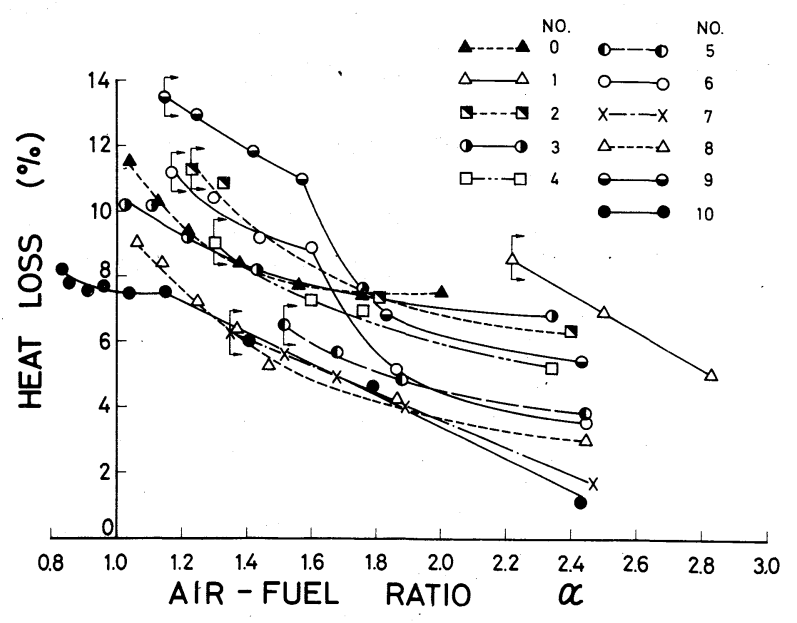

第 2 図 空気過㮃係数 $(\alpha)$ と熱損失との関係

c） $\alpha$ 值が 1.0 以下では当然不完全然焼しているが, $\alpha=0.8$ 程度までは 肉眼ではほとんど黒煙はみられない。しかし水中噴射すれば, 多少 水が污れる筈である。 


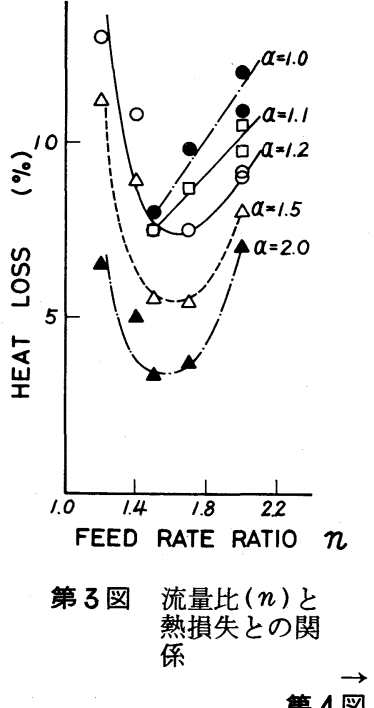

空気過㮃係数 $(\alpha)$ 熱焼筒 長さ $(L)$ 熱損失との関係

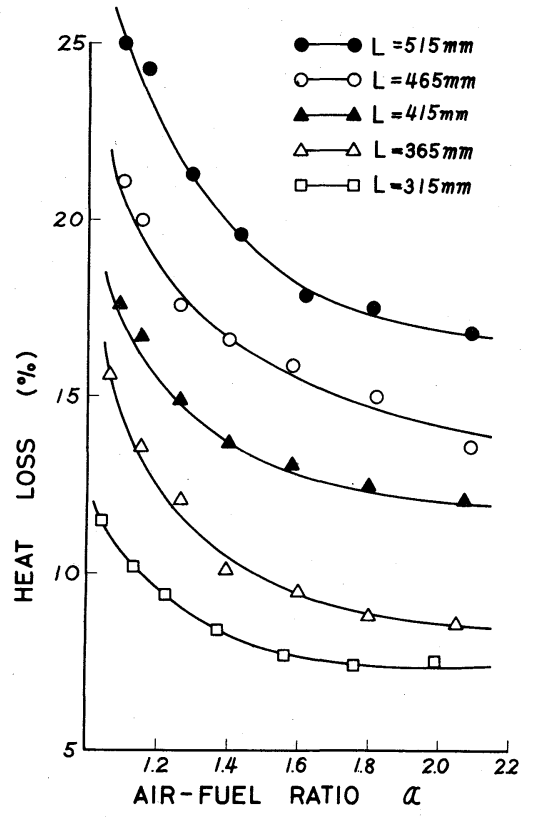

第 5 図 燃焼筒の長さ $(L)$ と熱損失との関係

$\tau:$ ガス滞留時間 ( sec)

ロケットエンジンでは, $\tau=0.002 \sim 0.007$
内径に対してその長さを変化させ，その熱損失量をチェッ クして, 直径 $(D)$ に対する最適長さを検討した。空気過剒 係数 $(\alpha)$ と然焼筒長さ $(L)$ を変化させた場合の, 熱損失の 変化を第 4 図に示している。 $\alpha$ 値の増加につれて, 火焰ジ ェットの温度自体が低下するので, 熱損失も減少する筈で ある。 $\alpha=1.0 \sim 1.4$ の間で熱損失の急激な減少がみられ る。

・燃焼筒の長さの影響を明らかにするために, 燃焼筒長さ $(L)$ ，あるいは直径との比 $L / D$ と熱損失量との関係にプロッ トしなおしたのが第 5 図である。 $\alpha$ 值の如何にかかわらず, $L$ の減少につれて熱損失は直線的に減少している。 $D=$ $109 \mathrm{~mm}$ のものに対して, $L=565 \mathrm{~mm}(L / D=5.18)$ の 場合は熱損失は $\alpha=1.2$ の場合約 $26 \%$ であるが, $L=315$ $\mathrm{mm}(L / D=2.89)$ に短かくすれば, 熱損失は約 $9.5 \%$ に

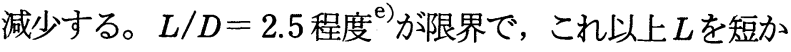
くすれば黒煙を発生するようになり，好ましくない。この 時の熱損失は $\alpha=1.2$ の場合，約 $7 \%$ となる。

\section{5. 燃焼筒容積の決定}

然焼筒容積 $(V)$ に関しては, その算定式として, ロケッ トェンジンの場合, 次の実験式が与えられている。

$$
V=\frac{G R T \tau}{P}
$$

ただし, $G$ : プロペラント量 $(\mathrm{kg} / \mathrm{sec})$

$R:$ ガス定数 $\left(\mathrm{kg} \cdot \mathrm{m} / \mathrm{kg} \cdot{ }^{\circ} \mathrm{K}\right)$

$T:$ 燃焼温度 $\left({ }^{\circ} \mathrm{K}\right)$

$P:$ 燃焼圧力 $\left(\mathrm{kg} / \mathrm{m}^{2}\right)$

d）燃焼筒内でのインジェクタ，スワーラ本体の取付位置を変えられる 構造の実験機を試作し, 同じ然焼筒内で $L$ の長さを次第に減少させ て実験した。したがつて, 燃焼筒直径 $(D)$ は変えていない。

e) $L / D=2.0$ の場合は, いかなる条件の場合にも, 黒煙が発生, 寸な わち不完全然焼した。 secとされている。われわれが開発したバーナでは， $\tau$ の 值を第 5 図の実験データを利用して求めると次のようにな る。 $G=0.07695 \mathrm{~kg} / \mathrm{sec}, R=29.27 \mathrm{~kg} \cdot \mathrm{m} / \mathrm{kg}^{\circ} \mathrm{K}, T=$ $2,400^{\circ} \mathrm{K}, P=7 \times 10^{4} \mathrm{~kg} / \mathrm{m}^{2}$ として $L / D=2.5 \sim 4.7$ に とると, この時の燃焼筒容積が $2,546 \sim 4,775 \mathrm{~cm}^{3}$ となる ので, これより $\tau=0.03 \sim 0.06$ となる。帯留時間 $\tau$ が一 桁大きい值を示すのは, 燃料として灯油, 酸化剤として圧 縮空気を使用しているためであろう。 $\tau=0.03 \sim 0.06$ と すれば，上式は設計計算に利用することができる。

\section{6. 過熱蒸気バーナ}

\section{$6 \cdot 1$ 構 造}

火焰ジェットバーナから噴射される火焰ジェットの温度 は, 最高 $2,000^{\circ} \mathrm{K}$ にも達するため, 可燃物や高温熱分解物 質の粉砕に火焰ジェットを用いることはできない。そのた め, 火焰ジェットの温度を任意に低下させる要求が生じた。 直接的に焰ジェットの温度を変化させることは不可能な ため, バーナ先端に過熱蒸気バーナ（第 6 図）を取付け, 一定量の水を供給することにより, 所定の過熱蒸気を発生 させることにした。過熱蒸気バーナ（第 7 図）は, 一本の 円筒状パイプで, その先端にはラバールノズルが取付けら れている。一定の水量が火焰ジェットに対して直角方向か ら, 火焰ジェットの噴射圧と同じ程度の圧力で圧入される。 この水は火焰シェットと混合し過熱水蒸気となり, 先端ノ ズルから噴射される。ノズルのデイメンションは, その過 熱蒸気の温度に対応して, 圧力 $5 \sim 6$ 気圧 ( 火焰ジェット 圧力 $6 \sim 6.5$ 気圧 ) になるように設計されている。

\section{2 供給水量亡過熱蒸気温度との関係}

供給水量を変化させ, 過熱蒸気バーナのノズル出口端よ り $100 \mathrm{~mm}$ 手前の所での温度 ( 第 7 図参照 ) を測定した。 その結果を第 8 図 ${ }^{\mathrm{f})}$ に示している。供給水量 $1.0 \mathrm{l} / \mathrm{min}$ の 


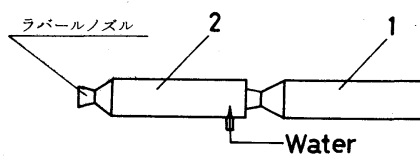

1. 火焰ジェットバーナ

2. 過熱蒸気バーナ

第 6 図過熱蒸気バーナの取付

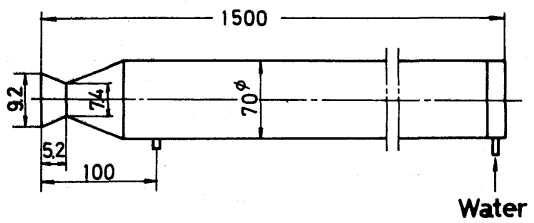

第 7 図

灯油流量 $0.1 \mathrm{l} /$

$\min$ の焰ジ ットバーナに対

する過熱蒸気バ

場合の温度約 $90^{\circ} \mathrm{C}, 0.5 \mathrm{l} / \mathrm{min}$ の場合約 $210^{\circ} \mathrm{C}, 0.2 \mathrm{l} /$ min の場合約 $440^{\circ} \mathrm{C}$ である。この図からわかるように, 供 給水量の変化により過熱蒸気の温度を, $200^{\circ} \mathrm{C}, 300^{\circ} \mathrm{C}$ 等 任意に変化させることができる。この過熱蒸気バーナは, ベークライトの粉砕等に偉力を発揮している。

\section{3 供給水量と温度に関する解析}

第 6 図に示すように, 火焰ジェットバーナに過熱蒸気バ 一ナを取付け, 一定量の水を供給し, ある温度の過熱蒸気 が発生した場合, 燃料 $1 \mathrm{~kg}$ 当りの式として, 次の式が成立 する。

$$
\begin{aligned}
& \left(1+G_{0}\right) C_{k} T_{1}+(\alpha-1) G_{0} C_{a} T_{1}+W C_{w} T_{1}^{\prime} \\
& -\frac{h F\left(t-t_{0}\right)}{q}=\left(1+G_{0}\right) C_{2}^{\prime} T_{2}+(\alpha-1) G_{0} C_{a}^{\prime} T_{2} \\
& +W C_{w} T_{0}+W r+W C^{\prime \prime}\left(T_{2}-T_{0}\right) \quad \ldots \ldots \ldots \ldots(2)
\end{aligned}
$$
ただし

- $\left(1+G_{0}\right) C_{k} T_{1}$ : バーナ噴射ガス ( 燃焼ガス) 熱量

$C_{k}:$ 燃焼ガス比熱

$T_{1}:$ 燃焼ガス温度

$G_{0} ：$ 燃料 $1 \mathrm{~kg}$ を完全燃焼させるに必要な空気量

$(\mathrm{kg})$

$$
\left(G_{0} \fallingdotseq 15 \mathrm{~kg} / \mathrm{kg}\right)
$$

- ( $\alpha-1) G_{0} C_{a} T_{1}$ : バーナ噴射ガス中の空気熱量

$C_{a}:$ 温度 $T_{1}$ のときの空気比熱

$\alpha$ : 空気過剩俰数

- $W C_{w} T_{1}^{\prime}$ : 供給水の熱量

$W:$ 供給水量 $\quad C_{w}:$ 水の比熱

$T_{1}^{\prime}:$ 供給水温度 $\begin{gathered}h F\left(t-t_{0}\right) \\ q\end{gathered}:$ 過熱蒸気バーナから大気中へ失なわれ

$h$ : 大気中への熱伝達俰数

$F$ ：過熱蒸気バーナの放熱面積

$t$ : 過熱蒸気バーナ外壁面温度

$t_{0}:$ 外気温度

$q$ : 供給燃料の量

・ $\left(1+G_{0}\right) C_{2}^{\prime} T_{2}$ : 過熱蒸気バーナ内におけけるガスの熱量

f）然料 $0.1 \mathrm{l} / \mathrm{min}$ 供給量の小型ジェットパーナを用い, 灯油の実流量 $0.085 \mathrm{l} / \mathrm{min}$, エヤ $1.45 \mathrm{~m}^{3} / \mathrm{min}$ で実験したデータによる。

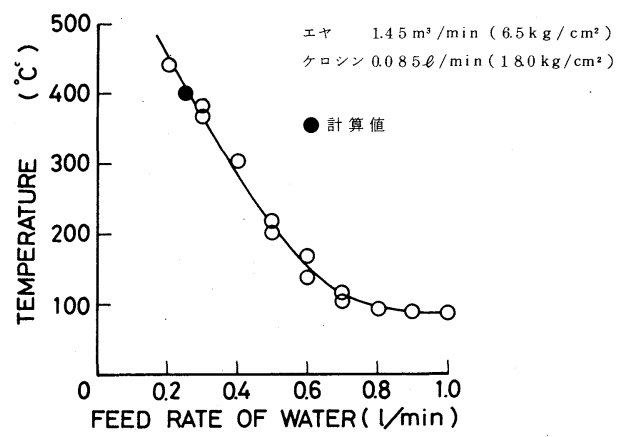

第8図 過熱蒸気バーナでの供給水量と過熱蒸気温度との関係

$C_{2}^{\prime}:$ 過熱蒸気バーナ内での噴射ガス比熱

- $(\alpha-1) G_{0} C_{a}^{\prime} T_{2}$ : 過熱蒸気バーナ内での過剰空気熱 量

$C_{a}^{\prime}$ :温度 $T_{2}$ に対する空気比熱

・ $W C_{w} T_{0}$ : 過熱蒸気バーナ内で水が気化温度に達する までに吸収する熱量

$T_{0}:$ 水の気化温度 $\left(100^{\circ} \mathrm{C}\right)$

- $W r$ : 水の気化熱量

$r$ : 水の気化潜熱 $(540 \mathrm{kcal} / \mathrm{kg})$

- $W C^{\prime \prime}\left(T_{2}-T_{0}\right)$ : 気化蒸気が過熱されるに必要な熱量 $C^{\prime \prime}:$ 過熱水蒸気の比熱

$T_{2}:$ 過熱蕰度

いま過熱蒸気温度を $400{ }^{\circ} \mathrm{C}\left(T_{2}=67: \mathrm{K}\right)$ にするのに 必要な供給水量を求めてみる。 $C_{k}=0.270$ ( $0.263 \sim$ $\left.0.287^{2)}\right) \mathrm{kcal} / \mathrm{kg} \cdot{ }^{\circ} \mathrm{C}, T_{1}=1,250^{\circ} \mathrm{K}, \alpha=1.75, C_{a}=$ $0.284 \mathrm{kcal} / \mathrm{kg} \cdot{ }^{\circ} \mathrm{C}, T_{1}^{\prime}=293{ }^{\circ} \mathrm{K}, h=7 \mathrm{kcal} / \mathrm{m}^{2} \cdot \mathrm{h} \cdot{ }^{\circ} \mathrm{C}$, $F=3.14 \times 7 \times 140=3,077 \mathrm{~cm}^{2}=0.3077 \mathrm{~m}^{2}, t-t_{0}=$ $350^{\circ} \mathrm{K}, q=0.085 \mathrm{l} / \mathrm{min}=0.006885 \mathrm{~kg} / \mathrm{min}=0.413$ $\mathrm{kg} / \mathrm{h}, C_{2}^{\prime}=0.260 \mathrm{kcal} / \mathrm{kg} \cdot{ }^{\circ} \mathrm{C}, T_{2}=673^{\circ} \mathrm{K}, C^{\prime \prime}=$ $0.489^{3)} \mathrm{kcal} / \mathrm{kg} \cdot{ }^{\circ} \mathrm{C}, C_{a}^{\prime}=0.255 \mathrm{kcal} / \mathrm{kg} \cdot{ }^{\circ} \mathrm{C}$ として計 算すると, $W=3.7 \mathrm{~kg}$ water $/ \mathrm{kg}$ fuel となる。燃料流量 $q=0.006885 \mathrm{~kg} / \mathrm{min}$ であるので, 所要水量は $3.7 \times$ $0.006885=0.025 \mathrm{l} / \mathrm{min}$ となる。実測値と大体一致す る。したがつて，上述の諸係数を採用すれば，(2)式によつ て, 過熱水蒸気バーナの下流側内部における, 混合ガスの 目標温度に対応する供給水量を推算することができる。

7. 火焰ジェット, 過熱蒸気バーナの利用について

以上述べてきた新型の火焰ジェットバーナと過熱蒸気バ 一ナは，いろいろな方面での利用が考えられる。現在すで に試みられているもの, あるいは今後利用を考えているも のについて述べる。

高性能新型火焰ジェットバーナは, これを高圧化 (25気 圧 ) したものを岩石 (石灰石, 珪石等) の微粉砕に利用し, 特に超微粉砕 ( 10 ミクロン以下) に偉力を発揮している。 低圧 ( 6 気圧程度 ) のものは, 各種産業廃棄物の脱水乾燥 用として, 過熱蒸気バーナは可燃性廃棄物の粉砕処理に好 ましい。また石炭のガス化にもテスト中であり，今後石炭 
の地下ガス化にも適用でさると考えている。さらに火焰ジ ェットバーナによるオイルサンドからの採油が試験中であ り, 将来は地下オイルサンド層までバーナを降下させ, 油 分を分離させ採油することも十分考えられ，あるい油層 からの二次回収 (火攻法) に，このバーナが利用できると 考六ており,さらに岩石の微粉砕が高能率に実施されるた め, オイルシェールからの採油を試験する予定である。オ イルシェールの粉砕と同時に, 油分の分離が性ずる筈で, 好結果が期待できる。

$$
\text { 8. を ぬ }
$$

岩石の熱削孔以外の目的に, 寸なおち岩石その他固形物 の粉砕や, 各種産業廃棄物の処理に用いる, 高能率火焰ジ ェットバーナと, 過熱蒸気バーナを開発した。以上の報告 事項をまとめると，次のようになる。

（1）新型火焰ジェットバーナは，圷縮空気噴射用に円錐 台状のスワーラ本体を用い, 压縮空气礼は孔群から噴射す るものと, 外縁に設けたスワーラ溝を流孔る旋回流に分け る構造とした。

(2) 燃焼筒内径 $(D)$ と燃焼筒長さ $(L)$ との関係を $L / D$ = 2.89 にとれば，熱口スを 10 \%以下とすることができる。 (3) スワーラ本体から噴射される空気流量比 $(n)$ は, $n=1.5$ の場合が最も安定した燃焼が得られ，熱ロスも少 ない。

（4）燃焼筒容積を求めるロケットエンジンの場合の実験 式で, 滞留時間 $\tau=0.03 \sim 0.06$ とすれば, 火焰ジェット バーナの設計に利用できる。

（5）過熱蒸気バーナの開発で，任意の温度の過熱蒸気ジ ェットを発生させうるようになつた。

（6）過熱蒸気バーナ設計計算に利用でさる。所定温度を 確保するのに必要な供給水量を求める計算式を示した。

（7）過熱蒸気バーナにより，有機物や可燃物を処理（粉 砕または脱水, 乾燥等) できるようになり，工業上での火 焰ジェットバーナの利用範用が拡大した。

謝辞＼cjkstart実験に協力された東大資源開発，杉浦助手，大 村助手, 二タ村技術員に謝意を表したい。

文

1) Е.Е. волков, Л.Г. головКов, Т. А. СЫРИцЫн : Жидкостные ракетные двигатели. 204, (1970), Москва.

2) М.И. ВЕЛИКИЙ, А. И. ЧЕРКОНОС, С. З. ВАЙМАН: Техника бурения скважин комбинированными способами. 20, (1977), Москва.

3) В.С. ЗУЕВ, В.С. МАКАРОН : Теория прямоточных и ракетно -прямоточных двигателей. 362, (1971), Москва.

On the Development of High Efficiency Supersonic Fire Jet Burner and Superheated Vapour Burner

by Zenjiro HOKAO ${ }^{1}$, Shohei SHIMADA ${ }^{2}$ and Keishi BABA ${ }^{3}$

The supersonic fire jet burner is now using not only for piercing of rocks, but for treatment of many kinds of industrial wastes or grinding of rocks into very fine particles. But the burner has a pretty high heat loss - about 25 to $27 \%$ of total heat generated in combustion chamber, for it was developed as a jet piercing machine which requires small diameter of combustion chamber. Length - Diameter ratio of combustion chamber in the jet piercing machine was usually 10 to 15 , and the amount of heat transferred across a surface of chamber was pretty large. Using of jet burner in grinding of rocks or treatment of wastes permits us to change the construction parameters, which decrease the heat loss of burner. The LengthDiameter ratio of combustion chamber of new developed high efficiency jet burner was reduced to about 3.0, and it has the heat loss less than $10 \%$. The authors developed also a special superheated vapour burner, temperature of which would be changed voluntary but contained the supersonic velocity of jet and high pressure. This type of burner is useful for drying or grinding of organic material or combustibles. The paper reports the construction of new developed burners and some results of experiments which carried out to determine the optimum parameters.

(1. Prof., Dr., Faculty of Engineering, The Univ. of Tokyo. 2. Associate Prof., Dr., Faculty of Engineering, The Univ. of Tokyo. 3. Graduate Student, The Univ. of Tokyo.

[自然銅シリーズ〕(3)

\section{ボリビア産自然銅}

東京虎ノ門の金属鉱業事業団本部の受付を入ると, すぐ左脇に自然銅の大塊がデー ンと置かれている。幅は約 $1.3 \mathrm{~m}$, 高さ約 $60 \mathrm{~cm}$, 厚さ $30 \mathrm{~cm}$ 近い大塊で, 重量は 100 $\mathrm{kg}$ 以上あ万うかと考えられる。

産地は南米ボリビアのチヤカリヤ銅山で同和鉱業が入手されたものを譲り受けられ たと, 前平塚保明理事長かららかがつた。同様な大塊が, 同社にも所蔵されている という。

全体の形態, 表面の状態等いずれも秩父和銅に似た点が多く, 自然銅の生成条件 がきわめて類似していただろうと推測できる。

(N.H.)

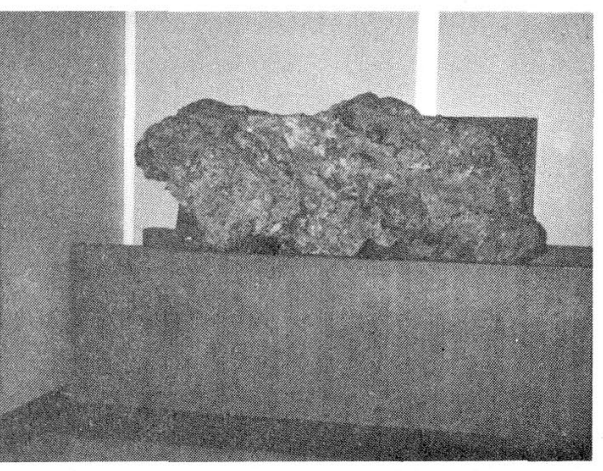

